DOI: https://doi.org/10.51209/platform.2.4.2021.330-351

УДК 7.08;792.7

\author{
Максим Володимирович ЛИТВИНЕНКО, \\ Київська муніципальна академія \\ естрадного та циркового мистецтв, \\ Київ, Україна, \\ e-mail: kafedraart@ukr.net, \\ ORCID: 000-0002-6808-3282
}

\title{
ГЕГ НА ЕСТРАДІ ТА У КЛОУНАДІ
}

Анотація. Природа сміху, гумору протягом століть $є$ предметом досліджень. Для багатьох єдина практична функція сміху полягає в тому, щоб принести тимчасове полегшення від тягаря утилітарності. Але сміх - це рефлекс, унікальний тим, що він служить явній біологічній і психологічній меті, тому його можна назвати рефлексом-розкішшю. Ще одна властивість сміху - заразливість. Психолог Роберт Провайн, який досліджував етологію сміху у людей, встановив, що люди сміються у тридцять разів частіше, коли вони знаходяться поруч з іншими людьми, ніж коли вони на самоті. Навіть коли люди сміються наодинці з собою, вони нерідко уявляють, що поруч із ними інші люди - вони читають текст, написаний іншою людиною, чують іiі голос по радіо чи бачать їі по телевізору. Люди сміються, коли чують сміх, саме тому в телевізійних комедіях використовуються аудіозаписи сміху, щоб компенсувати відсутність живої аудиторії. Попередником цього явища був барабанний дріб або удар по обідку барабана після жарту одного 3 комедіантів у водевілі. Сміх виражається за допомогою звуків не тільки тому, що він являє собою вивільнення накопиченої емоційної енергіï, а й тому, що так його можуть чути інші; сміх $\epsilon$ формою комунікації.

Спираючись на численні дослідження вчених, неможливо недооцінювати соціальну значимість артистів, що 
працюють у комічних жанрах. Таке явище дійсності для кожної людини має свої смислові ракурси.

Одним 3 найуніверсальніших видів мистецтв, простих, на перший погляд, і водночас дуже складних, є пантоміма. Щоб поставити пантомімічний номер - мімодраму, «тілесну міму», алегоричну або комічну пантоміму, потрібно знати й розуміти специфіку використання інструментарію даного різновиду мистецтва, бачити різницю між традиційною i класичною пантомімою; досконало володіти технікою пантоміми, видами ідентифікацій, рівнями стилізації, простими і складними видами руху, його біомеханікою, диференціювати алегорію і метафору, гротеск і ексцентрику в пантомімі, вміти створювати комічні трюки - геги. У цьому списку гег $є$ дуже потужним способом впливу на людські емоції і дуже рідкісним об'єктом наукових досліджень. Отже, розвідка спрямована на розширення, систематизацію і класифікацію, аналіз структурної одиниці комічного, процесу створення гега.

Ключові слова: пантоміма, гег, естрада, клоунада, комічне, сміх, театр

Вступ. Питання про природу сміху і гумору протягом століть $є$ предметом досліджень філософів і вчених. Г. Козинцев вважає, що сміх являє собою древній вроджений сигнал, тоді як гумор - явище культури, що виникло на базі тієї поведінки, частиною якого був цей сигнал. Для когось єдина практична функція сміху полягає в тому, щоб принести тимчасове полегшення від тягаря утилітарності. Сміх - це рефлекс, унікальний тим, що він служить явній біологічній i психологічній меті, тому його можна назвати рефлексомрозкішшю. Наступна властивість сміху - заразливість. Сміх виражається за допомогою звуків не тільки тому, що він являє собою вивільнення накопиченої емоційної енергії, а й тому, що так його можуть чути інші, це і форма комунікації.

Неможливо недооцінювати соціальну значимість артистів, що працюють у комічних жанрах. Таке явище дійсності для кожної людини має свої смислові ракурси. 
Постановка проблеми. Пантоміма - мистецтво, що має дуже різні підвиди, може бути комічною, драматичною, філософською, пластичною, буфонною, гротесковою. Визначення буфонної або гротескової пантоміми як клоунади $є$ не вірним. Підміна понять відбувається завдяки схожості засобам художньої виразності клоунади i пантоміми. Спорідненість методів полягає у використанні міміки, виразного жесту, пластики тіла, в особливих випадках, пантомімічної техніки, прийомів трансформації образу і предмета та специфіки побудови комічних трюків.

У системі виразних засобів циркового мистецтва особливе місце посідає трюк. Трюк є образною мовою манежу. Трюки - основа кожного з циркових жанрів, і в кожному є своя специфіка. Поняття «цирковий трюк» має широке коло значень. Але якщо в акробатиці, дресируванні, наїзництві, жонглюванні, словом, у будь-якому різновиді мистецтва цирку основна функція трюку - дивувати, то в мистецтві клоунади завдання трюку - смішити. Для зручності називатимемо трюки цього типу комічними. Комічний трюк - сміхова одиниця клоунського виступу, а також будь-якого комічного номеру; емоційний ефект будується на візуальному сприйнятті; завдяки дії фактору несподіванки, посилює комізм ситуації. Аналогічну сміхову одиницю в кінокомедії прийнято називати «гегом». Таким ємним лаконічним поняттям стали користуватися діячі естрадноциркових мистецтв.

Одним 3 найуніверсальніших видів мистецтв, простих, на перший погляд, і водночас дуже складних, є пантоміма. Щоб поставити пантомімічний номер: мімодраму, тілесну міму (термін Н.Я. Ужвенко) [19], алегоричну або комічну пантоміму, потрібно знати i розуміти специфіку використання інструментарію даного мистецтва. А саме: бачити різницю між традиційною і класичної пантомімою; досконало володіти технікою пантоміми, видами ідентифікацій, рівнями стилізації, простими i складними видами руху, біомеханікою руху; диференціювати алегорію і метафору, гротеск і ексцентрику в пантомімі; вміти створювати комічні трюки - геги. У цьому 
списку гег є дуже потужним способом впливу на людські емоції та дуже рідкісним об'єктом наукових досліджень. Отже, серед завдань даної розвідки $\epsilon$ розширення, систематизація i класифікація, аналіз структурної одиниці комічного, етапи та принцип створення ґега.

Аналіз останніх досліджень і публікацій. На сьогодні грунтовних, вузько спрямованих праць феномену гегу у вітчизняному мистецтвознавстві майже немає. Досліджувати явище доводиться, спираючись на певні групи джерел: загальні роботи з історії та теорії театру, естради, $[4 ; 5 ; 6 ; 7 ; 8 ; 9 ; 11 ; 12$; 19], філософсько-культурологічні штудії $[1 ; 2 ; 3 ; 10 ; 14 ; 21]$, об'єктом наукового інтересу яких є природа комічного, рецензії творів сценічного мистецтва, де зустрічаєься гег, відеоматеріали 3 номерами, в яких можна бачити гег та піддаваи його аналізу.

Мета статті полягає в дослідженні гегу як структурної одиниці комічного на матеріалі пантоміми і клоунади.

Виклад основного матеріалу Для дослідження причинно-наслідкового зв'язку виникнення комічного трюку нам доведеться заглибитися в історично-еволюційний процес формування такого феномену як «клоун». I передусім ми звернемося до Стародавньої Греції. Саме тоді з'явилися сільські блазні, що веселили народ у селах, показували пародії, смішили, жартували над перехожими. Незабаром найспритніші стали називатися «бомолохами». Партнером «бомолоха» був «бохвал». Перший був лідером, весь час вигравав і часто ображав бохвала, а коли у нього бракувало слів, він його бив. Веселуни були сільськими «колонус», а жарти бомолоха придбали таку саму форму i перекочували 3 Греції в Італію, де продовжували називатися «колонус». Проте значення стало іншим. Тепер це вже була людина 3 гострим гумором. Оскільки жарти цих веселунів були досить саркастичними і висміювали в людях погані риси, а афінський уряд був дуже демократичним, він знайшов у жартах позитивний вплив на моральний стан людей. Незабаром було вирішено популяризувати цей почин i жартівників почали запрошувати на виступи в театр. 
Бомолохи привнесли в театр естетику, карнавальну мову і виразність засобів. Комічні прийоми їх виступів стали основою клоунади. Вони використовували різний реквізит, спритність рук, жонгляж, ілюзії, разом зі стилем народної вистави. Але вони опиралися загальноприйнятим нормам, вели себе вільно, не обмежуючись традиційними умовностями, і незабаром це призвело до появи зовсім іншого героя - циркового персонажа. Він продовжив свій розвиток паралельно з театральним.

Існували ще декілька типів артистів того часу: «фліаки» були дуже акробатичні й динамічні, показували різні комічні падіння, «буфони» були карикатурними типажами, які носили гротескову маску 3 гриму на обличчі, користувалися несиметричними формами, широко розкривали роти, голили голову наголо. Їх одяг був з яскравими різнобарвними плямами, різні капелюхи-треуголки стали характерними ознаками комедії масок в Італії. Їх використовують і сучасні коміки.

«Гістріони» стали передтечею циркових артистів. У своїй театральній грі вони користувалися досвідом мімів Стародавнього Риму. Міські забавники-гістріони існували у всіх народів Свропи: у Франції їх називали жонглерами, в Німеччині - шпільманами, в Англії - менестрелями, в Італії за старовинним звичаєм - мімами, в Польщі - франтами, в Росії скоморохами. Гістріон був одночасно гімнастом, плясуном, музикантом, співаком, сказателем і актором. Він умів показувати дивовижні фокуси, ходив на руках, стрибав через кільце, робив у повітрі сальто, балансував на натягнутому канаті, жонглював ножами, кулями, палаючими смолоскипами, ковтав шпагу. I тут же міг танцювати - один або з партнером-жонглером, зіграти на дудці або віолі, заспівати веселу пісеньку, акомпануючи собі на барабані, показати номер із мавпочкою або ведмедем і розіграти 3 ними якусь комічну сценку. Популярність гістріонів у середньовічному місті була дуже велика. Гістріони були найяскравішими виразниками стихійного бунтарства народних мac.

Яскраво виражався цей бунтарський, антиаскетичний дух у діяльності вагантів. Ваганти, «бродячі клірики», були 
семінаристами, що не довчилися, або разжалуваними церковними служителями; вони виступали 3 пародійними латинськими піснями на церковні гімни i 3 пародіями на церковні обряди. У своїх вільнодумних піснях ваганти їдко висміювали жадібність, лицемірство, продажність і розпутство духовенства; не раз стріли їх сатири долітали до римської курії і разили особу самого папи. Ваганти відкрито вихваляли земні радості, любов, вино, веселощі.

Незабаром гістріони розділилися трубадурів, акробаті, еквілібристів, що згодом поклало початок цирковому мистецтву.

Свій подальший передцирковий розвиток гумористичний персонаж, прабатько клоунів, отримує в італійській народній комедії. Наприкінці XV ст. виникла «комедія дель арте». Актори, що виступали в ній, багато запозичили 3 досвіду гістріонів. Брігелла й Арлекін поступово втрачали обмеженість, грубість, набували привабливіших рис. По ходу п'єси слуги розігрували невеликі комічні сценки, т. зв. лацци, жонглювали, виконували сальто і піруети, літали над сценою, провалювалися в люки, показували фокуси. Перед артистами, що виступали в масках Брігелли i клоуна, що говорить, стояли тотожні завдання. Виконавці комедії дель арте вважали, що Брігелла повинен викликати захоплення своєю спритністю, а Арлекін - залучати співчутливі симпатії глядачів до своїх комедійних смутків і негараздів. У цирку теж побутувала традиція зображати клоуна не тільки смішним, але i спритним, тому багато артистів закінчували виступи акробатичними стрибками.

Маска Арлекіна справила великий вплив на формування типу циркового клоуна, який називають рудим. Як більшість циркових рудих, Арлекін не вмів швидко пристосовуватися до обставин і не володів життєвою спритністю Брігелли. Він був добрий, незлопам'ятний, надзвичайно простодушний і дурний. Якщо Брігелла командував, то другий слуга 3 веселою безтурботністю i безпорадною дурістю охоче підкорявся. Відзначимо, що в цирку такі взаємини лягли в основу багатьох клоунських дуетів. Арлекін діяв за натхненням, в стані 
райдужного світосприйняття і нерідко потрапляв у халепу. Вчинки випереджали думки.

Персонаж, названий «клоуном», вийшов на сцену англійського театру ще в XVI ст. Кожен його вихід перетворювався на самостійну інтермедію, не пов'язану 3 сюжетом п'єси. Тому багато драматурги спеціально залишали в п'єсах порожні місця в розрахунку на те, що клоун їх заповнить комічними трюками.

Однією з головних надзавдань театрального, циркового i будь-якого іншого виду мистецтва - досягти глядацького хвилювання, чи то сміху, сльоз, захоплення або огиди. Через неймовірно велику кількість зовнішніх і внутрішніх факторів, що впливають на реакцію людини на певний момент часу, немає сенсу розкривати питання, як і якою мірою людина відреагувала на побачене або почуте. Набагато конструктивніше проаналізувати феномен, який змушує одну частину людей, із покоління в покоління, старанно відточувати майстерність, а іншу половину - невтомно відвідувати естрадні, циркові та театральні майданчики. В обох випадках люди виконують подібні функції - розгойдують «маятник» цих мистецтв.

Що ж це за сила, здатна пробуджувати, виводити 3 рівноваги і знаходити відгук у душах людей? Відповідь проста. У циркових артистів цією силою є Трюк. «Його величність Трюк» - основоположний елемент циркового мистецтва. Залежно від жанру він поділяється на такі види: психологічнофізичний, технічний i акторський. До психологічно-фізичних трюків належать усі трюки циркових жанрів, головним засобом вираження яких є фізичні, психологічні можливості та здібності артиста, безпосередньо пов'язані або непов'язані з реквізитом (акробатика, жонгляж, гімнастика, атлетика, еквілібристика, дресура та ін). Технічний трюк впливає на глядача за допомогою спеціального реквізиту i технологій (ілюзія, клоунада, оригінальні жанри). Акторський трюк - це царина клоунади, пантоміми. Природно, у кожному 3 видів присутня акторська майстерність, спеціальний реквізит, певні фізичні і, тим більше, психологічні дані. Але підставою для поділу трюку на типи 
послужив критерій домінування однієї із складових у тому чи іншому жанрі.

Розглянемо детальніше особливості і методи побудови комічного трюку. У кожного виду мистецтва $є$ свої особливі засоби виразності для досягнення відповідного ефекту: сміху, посмішки, іноді просто задоволення, схвалення. Основною наочно-зоровою одиницею комічного ефекту саме в естрадноцирковому номері виступає комічний трюк - гег. Він являє собою самостійну одиницю, що має право існувати поза контекстом того, що відбувається, але органічно вплетений у тканину сюжету. «Гег - це несподівана для глядача зміна сценічної ситуації, запланована режисером або актором комічна ситуація, яка викликає сміх у глядачів і яку ніби спонтанно створює у критичні моменти сюжету персонаж, або в яку він потрапляє ніби несвідомо - в залежності від наявних певних рис характеру» [19, с. 117]. Комічний трюк будується виключно на візуальному, зоровому сприйнятті. Одна 3 головних умов у створенні комічного трюку - його несподіваність. У системі оригінальних жанрів, таких, як пантоміма, клоунада, музична ексцентрика, маніпуляція і фокуси і т.п., комічний трюк $\epsilon$ могутнім засобом виразності.

За виконанням комічні трюки можна поділити на механічні та тілесні. Якщо перші засновані на застосуванні технічних пристосувань, то для других матеріалом служить лише треноване тіло артиста. Наприклад, механічний трюк у клоунаді - «фонтан сліз», або Тантамореска — на ширмі висотою по плечі закріплювалися ляльки 3 ногами і руками. Загримований актор просовував руки і голову в отвори, а інший актор керує ногами ляльок.

Комічні трюки поділяють і за змістом: «прохідні» i «сюжетні». Перші дуже короткі і виконуються немов «між іншим». Другі - розгорнуті за часом і смисловим наповненням. Трюки другого типу можуть служити підвалинами, на яких будується цілий номер.

Аналізуючи дослідження Артура Кестлера, британського письменника та журналіста, в галузі гумору, розглянемо одну зі 
схем, якими гумористи й коміки того часу впливали на наявний у мисленні інвентар систем правил, способів інтерпретацій, образів думок і систем координат глядачів. «Гумор починається 3 нитки міркувань в одній системі координат, яка стикається 3 невідповідністю: подією або твердженням, що не має сенсу в контексті всього, що було до цього. Невідповідність можна вирішити, перейшовши до іншої системи координат, в якій подія буде мати значення. А в цій системі відліку положення даної людини буде применшено. Кестлер називає цей перехід «бісоціацією». Багато прикладів гумору, що наводяться Кестлером, непідвладні часу. Як приклад: леді Астор каже Вінстону Черчиллю: «якби ви були моїм чоловіком, я б підсипала вам в чай отрути». Він відповідає: «Якби ви були моєю дружиною, я б ії випив». Ця відповідь парадоксальна 3 точки зору системи координат вбивства, тому що зазвичай людям не хочеться бути вбитими. Невідповідність досягається шляхом перемикання на систему координат самогубства, в якій смерть є бажаним порятунком від страждань. У цій системі координат леді Астор - причина невдалого шлюбу, а це далеко не найкраща роль...» [12]. Поняття «бісоціації» також застосовується у будь-якому іншому комічному жанрі і комічній формі.

Тією чи іншою мірою «бісоціацію» Кестлера іншими словами можна назвати - алогізмом, тобто зіткнення двох систем координат. Алогізм є підвалинами для гега - не логічне міркування, хід думки що порушують закони і правила логіки, або факт, який не вкладається у рамки логічного мислення, те, що суперечить логіці. Грунтуючись на даному понятті, вирішимо два завдання: доповнимо існуючу класифікацію гегів, проаналізуємо методи побудови комічного трюку, які підходять як для артистів як пантоміми, так і клоунади.

Розглянемо структуру побудови гегів певних типів. Наприклад, гег «Прибудова». Створюється як прибудова до конфліктної події або реакції партнера. Прикладом для цього гега послужить номер канадського коміка та актора пантоміми Мішеля Куртеманша «Klaustrofóbia»: мім чекає на ліфт, хоче 
засунути руки в кишені, але продіває руки пов3, бо кишень немає; намагається поставити лікоть на опору, але i iï поруч немає, намагається скласти руки на грудях, але і це не виходить; у підсумку, не знаючи куди подіти руки, стає в «дурну» позу, засовуючи руки під пахви, як мавпа. Розбираючи цей гег, потрібно відзначити, що якби персонаж відразу став у фінальну позу, актор не домігся б бажаного ефекту. Саме тому потрібно слідувати певній структурі побудови гега.

Зведена дія або подія до ступеня абсурду має назву «гіперболізація». Таку структуру гега дуже яскраво і зрозуміло використовував, наприклад, мім-клоун Дмитро Богатирьов у своєму номері «Навчальна тривога». Солдат, перед тим як одягнути черевики, намотує онучу на ногу, онуча не закінчується, намотує їі далі на тіло вона знов не закінчується, обмотує навколо шиї, кінець закидає на плече, як шарф художника [4]. Чим незвичніша кожна подальша дія, вихід із ситуації, тим яскравіша реакція глядача.

Структура наступного гега лежить у його назві: «ускладнення явно простого завдання». У своїй півгодинній шоу-виставі Грок. швейцарський клоун, який був названий «королем клоунів» і «найвеличнішим клоуном Європи», маючи намір зіграти композицію на фортепіано, замість того, щоб підсунути стілець до рояля, 3 великими труднощами підсовує рояль до стільця. В одному з номерів Андрія Жигалова і Джаба Сцегю конфлікт будується на тому, що вокаліст не може заграти на флейті, бо Жигалов, «установник мікрофонної стійки», не може і не хоче їі правильно ставити. Замість того, щоб опустити мікрофон на рівень голови вокаліста, клоун намагається підняти музиканта; якщо потрібно встановити трохи вище мікрофон, він піднімає всю стійку, замісць того, щоб іiі просто розігнути.

Гег «Закон трьох» побудований наступним чином: перші дві дії йдуть логічно, третя - алогічно. Оскільки номери клоуна Андрія Жигалова наповнені великою кількістю гегів, ми будемо часто звертатися до них за допомогою. I тому для прикладу знову візьмемо його номер. Звертаючись до публіки, клоун просить їі кілька разів повторити слова: перший раз клоун каже 
фразу 3 пісні, глядачі повторюють; другий раз - іншу фраза 3 пісні, глядачі повторюють; на третій раз те саме повторюєься 3 абсурдним звуком.

Гег «Невдаха» - це незграбне виконання будь-якої дії.

Гег «Загрався» - вирішення конфліктної ситуації 3 суб'єктом чи об'єктом з метою досягти бажаного результату, мета забувається i починається загравання 3 даною ситуацією. Приклад: клоун хоче пройти через арочний металодетектор, у нього не виходить, тому що детектор постійно спрацьовує; клоун просовує одну руку, видається сигнал в одній тональності, просовує ногу - сигнал видозмінюється, просовує другу руку знову змінює тональність; забуваючи про свою мету, клоун починає по черзі просовувати руки і ноги, тим самим складаючи певну мелодію; глядачі винагороджують клоуна оплесками, після того, як впізнають мелодію. У репризі Андрія Жигалова клоун, знущаючись над флейтистом, не дає йому почати свій виступ. Поправляючи рукою мікрофонну стійку, клоун провокує глухий звук удару, починає бити ії сильніше, ніби боксер у спарингу.

Наступний гег неодноразово використовувався в кінематографі, оскільки його структура відмінно передбачає наявність безлічі персонажів і паралельних історій. «Не звідти» - це поява персонажа в певний момент дії, невідповідного до контекста драматургії епізоду. Прикладом $є$ номер «Нізя» в одному 3 виступів театру «Лицедеи», коли у сценку вірвався персонаж із зовсім іншого номеру [38].

Принцип гегу «безпорадність» - це відсутність елементарних здібностей, необхідних для виконання дії. Приклад: у фільмі «Граф» герой Чарлі Чапліна, прийшовши в гості, накидається на величезний шматок кавуна без вилки i ножа. Через деякий час їсти кавун стає незручно, тому що обличчя все глибше йде в м'якоть, а гострі кінці кірки лізуть у вуха. Тоді він обв'язує голову серветкою, немов у нього болять вуха, замість того, щоб розрізати шматок на частини.

Дуже поширений у кінематографі та в комедійних жанрах сценічних мистецтв гег - «Ненавмисно». Згадуваний 
вище А. Жигалов, маючи намір помститися флейтисту за те, що він йому підлив води в шапку, намагається те саме провернути і 3 ним. Крадучись до музиканта 3 наповненою чашкою, Жигалов лякається, коли той обертається на нього, і ховає чашку собі в штани. Таке безглузде випадково прийняте рішення викликає сміх публіки. Продовжуючи аналіз цієї репризи, ми зустрічаємо ще один гег - «облом». Друга спроба налити води в циліндр флейтиста завершується вдало, але коли артист одягає головний убір, вода не виливається. Від такого повороту глядачі приходять у ще більший захват.

Гег «не той» належить до одного $з$ простих типів гегів замість очевидної взаємодії з одним партнером помилково або цілеспрямовано артист продовжує взаємодію 3 іншим партнером. В одній із реприз комік-тріо «Еківокі», володарі циркового «Оскара», а саме - «Бронзового клоуна» (цирковими «Оскарами» називають призи найпрестижнішого міжнародного фестивалю циркового мистецтва в Монте-Карло, що проводиться під патронатом княжої сім'ї Монако), поряд 3 безліччю інших типів гегів, використовують цей нехитрий, але дієвий гег, «не той». Найправильніший клоун за пустощі і несерйозність виконання поставленого завдання хоче вдарити іншого клоуна газетою, але той відвертається, в цей самий момент, підходить третій і випадково отримує стусана ні за що.

У цій самій репризі, «Літаки», 3 попереднього гега логічно випливає його наступний тип - «за інерцією», тобто безперервно-циклічне повторення будь-якої дії. Приклад: один клоун б'є іншого газетою по обличчю, замахується другий раз, той прикривається, замахується втретє, вчетверте прикривається, перший клоун відходить убік, другий продовжує бесперервно прикриватися. У своїй праці «Сміх» Анрі Бергсон пояснює, чому рухи людського тіла смішні, якщо тіло викликає в нас уявлення про простий механізм: «Ось, наприклад, у оратора жест змагається зі словом. Заздрячи слову, він весь час женеться за думкою і вимагає також і собі ролі Тлумача. Нехай так, але він повинен постійно слідувати за ходом думки, за всіма ії змінами. Думка - це щось безперервно зростаюче: від початку мови і до іï 
кінця вона пускає бруньки, квітне, зріє. Ніколи вона не зупиняється, ніколи не повторюється. Вона повинна невпинно змінюватися, тому що перестати змінюватися - значить перестати жити. Нехай же і жест живе подібно до неї! Нехай же і він підкориться основному закону життя, що $є$ в тому, щоб ніколи не повторюватися! Але ось мені здається, що один і той самий рух руки або голови періодично повторюється. Якщо я це помітив, якщо цього достатньо, щоб привернути мою увагу, якщо я чекаю його в певному місці і він відбувається у той момент, коли я його чекаю, - я мимоволі розсміюся. Чому? Та тому що тоді переді мною буде автоматично діючий механізм. Це вже не життя, це щось автоматичне, впровадити в життя і наслідує йому. І це - комічно» [2, сс. 27-28].

Наступний гег - «Людина-Предмет». Сутність полягає у перенесенні внутрішніх або зовнішніх якостей, в тому числі механіки руху, будь-якого роду речі, людині. Ось що з цього приводу думає А. Бергсон: «Наш сміх збуджувало миттєве перетворення особистості на річ, якщо завгодно поглянути на це під таким кутом зору. Перейдемо тепер від точного поняття про механічне до невизначеного поняття речі взагалі. Перед нами буде новий ряд смішних образів, отриманих внаслідок, так би мовити, затушовування контурів перших уявлень; i вони приведуть нас до нового закону: ми сміємося щоразу, коли особистість справляє на нас враження речі. Ми сміємося над Санчо Пансою, коли його кидають на ковдру і підкидають у повітря, як простий м'яч. Ми сміємося над бароном Мюнхгаузеном, коли він перетворюється на гарматне ядро i летить у простір. Але деякі вправи циркових клоунів дозволять нам, мабуть, ще точніше перевірити цей закон» [2, с. 42]. Явний приклад цього гегу присутній у творчості Джеймса Тьєрі, онука Чарлі Чапліна, в його мультижанровому спектаклі «Симфонія хруща». В одному з епізодів Тьєррі хоче зняти кофту, але в нього не виходить. На цьому конфлікті побудована окрема пластична сцена. Наприкінці він все ж знімає іiі, складає кілька разів навпіл, за чим складає і себе. Таку саму структуру гега він використовує в опереті «Летюча миша», фрагмент «на балі у графа 
Орловського»: не бажаючи танцювати з мужикуватою жінкою, Тьєррі всіляко намагається вирватися від неї, в результаті чого вона його б'є; Джеймс, створюючи ілюзію механіки ляльки, падає на підлогу [18]. Ще одним прикладом є пантомімічний номер (на звукоімитації) Мішеля Куртеманша «Le Western». На початку номеру товстун насилу підходить до телевізора, включає його i, в той момент, коли він відходить назад, щоб сісти у крісло, звукоімітує сигнал, який видає автомобіль, коли здає назад.

Одним iз найпростіших i, водночас, складних $\epsilon$ «Фізіологічний» гег. Складний, тому що потрібно точне розуміння, в який момент і за яких обставин людська фізіологія викличе сміх і не буде вульгарно чи огидно виглядати зі сцени. У тому ж номері «Le Western» після того, як головний герой поспілкувався $з$ глядачем своїм чоловічим низьким басом, дуже швидко скаче на своєму коні по пустелі; зупиняє жеребця i, тримаючись за пах, каже в зал тенором.

При створенні пантомімічних робіт міми часто використовують деякі анімаційні прийоми. Звідси і народжується наступний тип гега - «мультиплікаційний». Цьому типу $\epsilon$ величезна кількість прикладів. Розглянемо номер німецького міма Роба Спенса «Стоматолог»: лікар хапає пацієнта, що бігає по колу, саджає його у крісло, намагається відкрити йому рот руками - не виходить, відкриває рот ломом, дивиться - нічого не бачить, просовує у рот руку по лікоть, після чого залазить у пацієнта цілком, виявляє проблему і вилазить через «п'яту точку.

Наступні два приклади взяті 3 досвіду до Київської муніципальної академії естрадного і циркового мистецтв. Олексій Красних у клоунсько-пантомімічній репризі під назвою «Тихо» використовує багато анімаційних прийомів. Наприклад, надуває жабу, після чого використовує іï як м'яч; діставши черв'яка з банки для наживи, розтягує його і стрибає, ніби на скакалці, потім робить із нього качечку і пускає по річці; піймавши на гачок рибу, дістає іiі 3 величезним зусиллям, діставши, виявляється що рибка розміром із мізинець. 
Приклад із творчого досвіду міма Павла Вишневського номер «Пожежний». Приїхавши до палаючого будинку, старий пожежний виявляє відсутність води в баку, усвідомивши безвихідність ситуації, вирішує їхати назад на базу, але, почувши крик дівчини у палаючому будинку, перетворюється на суперпожежного; рятуючи дівчину, викидає іiі з вікна другого поверху, стрибає за нею, але тривалість вільного падіння незрівнянно велика з висотою другого поверху; злякавшись того, що відбувається, дівчина 3 криками тікає, від перенапруги у старого пожежного зупиняється серце, але, почувши звук сирени, він перетворюється на зомбі-пожежного та їде рятувати людей. Історія спочатку реалістична, поступово наповнюючись мультиплікаційними ефектами, викликає сміхову реакцію глядача.

Гег «Відсилання» - органічно вплетена ситуація, реакція, жест, запозичений із будь-якого твору мистецтва іншого жанру. Австралійський комічний дует «The Umbilical Brothers», виступаючи на телебаченні, показували номер «20 Cents», в якому дуже вдало вставлене посилання на фільму «Термінатор». Сутність номеру полягає в тому, що мийник вікон без згоди водія помив його вікно і просить у нього двадцять центів; водій відмовляється платити і їде, мийник починає переслідування; в цьому процесі мийник застрибує на автомобіль і дереться по даху, чіпляючись за нього металевими гаками замість рук, як «рідкий метал» у славнозвісному фільмі.

Висновки. Приймаючи правила гри, послуговуючись інструментарієм того чи іншого жанру, ми занурюємося у штучно створений світ. Виникає почуття віри в те, що персонажу дійсно притаманне таке нестандартне мислення і не правильне, в хорошому сенсі, бачення світу навколо. Віра в запропоновані обставини, в першу чергу, - актора i, отже, глядача, в комплексі з нелогічним і несподіваним способом вирішення проблеми викликає у публіки сміх.

Естетичне обгрунтування природи комічного трюку, творчо перетвореного 3 елементарної демонстрації м'язової натренованості на осмислене видовище, уподібнене за силою 
емоційного впливу театру. Різна естетична цінність трюків, неоднакове їх змістове наповнення, несхожість сміхового заряду: одні здатні викликати вибухове реготання, інші - лише посмішку, проте загальне для всіх трюків - їх роль у художній системі естрадно-циркових мистецтв - роль одного 3 могутніх засобів виразності.

\section{Список використаної літераури:}

1. Бергсон А. Смех. Москва: Искусство, 2010. 318 с.

2. Бергсон Г. Смех в жизни и на сцене. Москва:

Искусство, $1992.127 \mathrm{c.}$

3. Биллевич В. Школа остроумия или как научиться шутить. Москва: Издательский дом «Вильяме», 2008. 336 с.

4. Гэг и реприза - основные структурные единицы комического

в эстрадной программе.

URL: https://studfiles.net/preview/6013503/page:5/

5. Его Величество гэг. URL: http://zurblog.ru/?p=154

$6 . \quad$ Заметки о комическом трюке.

URL: http://www.ruscircus.ru/14226/

7. Зуев В. Юмор в разных жанрах. Санкт-Петербург:

Родные просторы, 2006. 180 с.

8. История возникновения пантомимы.

URL: https://megapredmet.ru/1-47036.html

9. Йеринг Г., Марсо М. Всемирное искусство пантомимы.

Театрон. 2008. Вып. 1. Сс. 74-88.

10. Карасёв Л. Философия смеха. Москва: Российский гуманитарный университет, 1996. 224 с.

11. Козинцев Г. О комическом, эксцентрическом и гротесковом искусстве. Собр. соч. в 5 тт. Ленинград: Искусство, $1983.85 \mathrm{c}$.

12. Краткая теория смеха: для чего человеку нужен юмор?

URL: https://theoryandpractice.ru/posts/15807-kratkaya-teoriyasmekha-dlya-chego-cheloveku-nuzhen-yumor

13. Природа комического в эстрадном номере.

URL: https://infopedia.su/1xa45e.html 
14. Пропп В. Проблемы комизма и смеха. Москва: Лабиринт, 1999. 288 с.

15. Райан. П. Актерский тренинг искусства быть смешным и мастерства импровизации. Санкт-Петербург: ПраймЕВРОЗНАК, 2010. $313 \mathrm{c.}$

16. Славский Р. Заметки о комическом трюке. 1986.

URL: http://www.ruscircus.ru/o_komicheskom_tryuke_776

17. Славский Р. Искусство пантомимы. Москва: Искусство 1962. $140 \mathrm{c}$.

18. Терентьева И. Тотальная клоунада: Про людей и лицедеев.

Санкт-Петербург: Геликон Плюс, 2006. 388 с.

19. Ужвенко Н., Скрябіна Н. Пантоміма у питаннях та

відповідях. Київ: Мистецтво, 2013. 117 с.

20. Что такое гэг.

URL: https://dic.academic.ru/dic.nsf/ruwiki/438762

21. Эстетические функции комического.

URL: http://toperhumor.blogspot.com/2010/04/blog-post.html

\section{Максим Владимирович ЛИТВИНЕНКО,}

Киевская муниципальная академия

эстрадного и циркового искусств,

Киев, Украина,

e-mail: kafedraart@ukr.net,

ORCID: 000-0002-6808-3282

\section{ГЭГ НА ЭСТРАДЕ И В КЛОУНАДЕ}

Аннотация. Природа смеха, юмора на протяжении веков является предметом исследований. Для многих единственная практическая функция смеха заключается в том, чтобы принести временное облегчение от бремени утилитарности. Но смех-это рефлекс, уникальный тем, что он служит явной биологической и психологической цели, поэтому его можно назвать рефлексомроскошью. Еще одно свойство смеха - заразительность. Психолог Роберт Провайн, который исследовал этологию смеха у людей, обнаружил, что люди смеются в тридцать раз чаще, 
когда они находятся рядом с другими людьми, чем когда они в одиночестве. Даже когда люди смеются наедине с собой, они нередко представляют, что рядом с ними другие люди - они читают текст, написанный другим человеком, слышат его голос по радио или видят его по телевизору. Люди смеются, когда слышат смех, именно поэтому в телевизионных комедиях используются аудиозаписи смеха, чтобы компенсировать отсутствие живой аудитории. Предшественником этого явления был барабанная дробь или удар по ободу барабана после шутки одного из комедиантов в водевиле. Смех выражается с помощью звуков не только потому, что он представляет собой высвобождение накопленной эмоциональной энергии, но и потому, что так его могут слышать другие; смех является формой коммуникации.

Опираясь на многочисленные исследования ученых, невозможно недооценивать социальную значимость артистов, работающих в комических жанрах. Такое явление действительности для каждого человека имеет свои смысловые ракурсы.

Одним из самых универсальных видов искусств, простых, на первый взгляд, и в то же время, очень сложных, является пантомима. Чтобы поставить пантомимический номер - мимодраму, «телесную миму», аллегорическую или комическую пантомиму, нужно знать и понимать специфику использования инструментария данного разновидности искусства, видеть разницу между традиционной и классической пантомимой; в совершенстве владеть техникой пантомимы, видами идентификаций, уровнями стилизации, простыми и сложными видами движения, его биомеханикой, дифференцировать аллегорию и метафору, гротеск и эксцентрику в пантомиме, уметь создавать комические трюки гэги. В этом списке гег является очень мощным способом воздействия на человеческие эмоции и очень редким объектом научных исследований. Итак, разведка направлена на расширение, систематизацию и классификацию, анализ структурной единицы комического, процесса создания гэга. 
Ключевые слова: пантомима, гэг, эстрада, клоунада, комическое, смех, театр

\section{Maxim V. LITVINENKO,}

Kyiv Municipal Academy of Circus and Performing Arts,

Kyiv, Ukraine,

e-mail: kafedraart@ukr.net,

ORCID: 000-0002-6808-3282

\section{GAG IN PERFORMING ARTS AND IN CLOWNING}

Abstract. The nature of laughter and humor has been the subject of research for centuries. For many people, the only practical function of laughter is to bring temporary relief from the burden of utilitarianism. But laughter is a reflex, unique in that it serves a clear biological and psychological purpose, so it can be called a luxury reflex. Another property of laughter is contagiousness. Psychologist Robert Provine, who has researched the ethology of laughter in humans, writes that people laugh thirty times more often when they are around other people than when they are alone. Even when people laugh alone with themselves, they often imagine that other people are next to them - they read a text written by another person, hear his voice on the radio or see him on TV. People laugh when they hear laughter, which is why television comedies use audio recordings of laughter to compensate for the lack of a live audience. The predecessor of this phenomenon was a drum roll or a blow on the rim of a drum after a joke by one of the comedians in vaudeville. Laughter is expressed through sounds not only because it represents the release of accumulated emotional energy, but also because it can be heard by others; laughter is a form of communication.

Based on numerous studies by scientists, it is impossible to underestimate the social significance of artists working in comic genres. Such a phenomenon of reality for each person has its own semantic angles.

One of the most universal types of art, simple at first glance, 
and at the same time, very complex, is pantomime. To stage a pantomime number - a mimodrama, a "body mime" an allegorical or comic pantomime, we need to know and understand the specifics of using the tools of this kind of art, to see the difference between traditional and classical pantomime; master the technique of pantomime, types of identifications, levels of stylization, simple and complex types of movement, its biomechanics, differentiate allegory and metaphor, grotesque and eccentricity in pantomime, be able to create comic tricks. In this list, geg is a very powerful way of influencing human emotions and a very rare object of scientific research. So, intelligence is aimed at expanding, systematizing and classifying, analyzing the structural unit of the comic, the process of creating a gag.

Key words: pantomime, gag, performing arts, clowning, comic, laughter, theater

\section{References:}

1. Bergson, A. (2010). Smekh [Laughter]. Moscow: Iskusstvo [in Russian]

2. Bergson, G. (1992). Smekh v zhizni i na stsene [Laughter in life and on stage]. Moscow: Iskusstvo [in Russian]

3. Billevich, V. (2008). Shkola ostroumiya ili kak nauchit'sya shutit' [School of wit or how to learn to joke]. Moscow: Izdatel'skiy dom "Vil'yame" [in Russian]

4. Geg i repriza - osnovnyye strukturnyye yedinitsy komicheskogo $\mathrm{v}$ estradnoy programme [The gag and the reprise are the main structural units of the comic in the pop program]. Available at: https://studfiles.net/preview/6013503/page:5/ [in Russian]

5. Yego Velichestvo geg [His Majesty the gag]. Available at: http://zurblog.ru/?p=154 [in Russian]

6. Zametki o komicheskom tryuke [Comic trick notes.]. Available at: http://www.ruscircus.ru/14226/ [in Russian]

7. Zuyev, V. (2006). Yumor v raznykh zhanrakh [Humor in different genres]. Sanct-Petersburg: Rodnyye prostory [in Russian] 
8. Istoriya vozniknoveniya pantomimy [The history of the emergence of pantomime]. Available at: https://megapredmet.ru/147036.html [in Russian]

9. Yyering, G.\& Marso, M. (2008). Vsemirnoye iskusstvo pantomimy [The universal art of pantomime]. Teatron,1, 74-88 [in Russian]

10. Karasov, L. (1996). Filosofiya smekha [Philosophy of Laughter]. Moscow: Rossiyskiy gumanitarnyy universitet [in Russian]

11. Kozintsev, G. (1983). O komicheskom, ekstsentricheskom i groteskovom iskusstve [On the comic, eccentric and grotesque art]. Sobr. soch. v 5 tt. Leningrad: Iskusstvo [in Russian]

12. Kratkaya teoriya smekha: dlya chego cheloveku nuzhen yumor [Brief theory of laughter: what does a person need humor for?]? Available at: https://theoryandpractice.ru/posts/15807kratkaya-teoriya-smekha-dlya-chego-cheloveku-nuzhen-yumor [in Russian]

13. Priroda komicheskogo $\mathrm{v}$ estradnom nomere [The nature of the comic in the stage number]. Available at: https://infopedia.su/1xa45e.html [in Russian]

14. Propp, V. (1999). Problemy komizma i smekha [Problems of Comedy and Laughter]. Moscow: Labirint [in Russian]

15. Rayan, P. (20100. Akterskiy trening iskusstva byt' smeshnym i masterstva improvizatsii [Acting training of the art of being funny and mastery of improvisation]. Sanct-Petersburg: Praym-YEVROZNAK [in Russian]

16. Slavskiy, R. (1986). Zametki o komicheskom tryuke [Notes on a comic trick]. Available at: http://www.ruscircus.ru/o_komicheskom_tryuke_776 [in Russian] 17. Slavskiy, R. (1962). Iskusstvo pantomimy [The art of pantomime]. Moscow: Iskusstvo [in Russian]

18. Terent'yeva, I. (2006). Total'naya klounada: Pro lyudey i litsedeyev [Total clowning: About people and actors]. SaintPetersburg: Gelikon Plyus [in Russian] 
19. Uzhvenko, N.\& Skryabina, N. (2013). Pantomima u pytannyakh ta vidpovidyakh [Pantomime in matters and answers]. Kyiv: Mystetstvo [in Ukrainian]

20. Chto takoye geg [What is a gag]. Available at: https://dic.academic.ru/dic.nsf/ruwiki/438762 [in Russian]

21. Esteticheskiye funktsii komicheskogo [Aesthetic functions of the comic]. Available at: http://toperhumor.blogspot.com/2010/04/blog-post.html [in Russian] 